\title{
The coastal restinga vegetation of Pará, Brazilian Amazon: a synthesis
}

\author{
RACHEL MACEDO DA SILVA ${ }^{1}$, ULF MEHLIG ${ }^{2}$, JOÃO UBIRATAN MOREIRA DOS SANTOS ${ }^{3}$ \\ and MOIRAH PAULA MACHADO DE MENEZES 2,4
}

(received: December 09, 2009; accepted: September 16, 2010)

\begin{abstract}
The coastal restinga vegetation of Pará, Brazilian Amazon: a synthesis) The present article reviews studies (some unpublished) of the vegetation of coastal sandy soils (restinga) along the coast of Pará State, northern Brazil. A total of 411 higher plant species are reported; Fabaceae, Poaceae, Cyperaceae, Rubiaceae and Myrtaceae are the most species-rich families. Nearly half of the restinga species (48\%) are terrestrial herbs; palms, trees and shrubs account for 39\% of the species, the remainder being lianas and epiphytes. Species are frequently wide-spread and occur in coastal areas of Southeastern Brazil as well as at inland sites in the Amazon region. Only two species appear to be exclusively coastal; whereas other species appear to exhibit a preference for sandy soils. Plant assemblages are commonly classified by means of "formations" associated with certain habitats but current data do not allow the description of well-defined plant associations. The species composition at different sites along the Pará coast does not show any clear regional grouping pattern. Seasonal changes in the composition of restinga vegetation are most probably linked to variation in ground water level. Restinga forest is mostly low and open; among the dominant tree species are Humiria balsamifera Aubl., Pouteria ramiflora (Mart.) Radlk., Anacardium occidentale L., Byrsonima crassifolia (L.) Kunth, and Tapirira guianensis Aubl.
\end{abstract}

Key words - coastal forest, dune vegetation, sandy coastal plain

RESUMO - (Vegetação de restinga do Estado do Pará, Amazônia Brasileira: uma síntese). Este artigo apresenta uma revisão dos estudos (alguns não publicados) da vegetação de restinga da costa do Estado do Pará, na região norte do Brasil. Ao todo foram registradas 411 espécies de plantas vasculares, sendo as famílias Fabaceae, Poaceae, Cyperaceae, Rubiaceae e Myrtaceae as mais ricas em espécies. Dentre as espécies da restinga, 48\% são ervas terrestres, 39\% são palmeiras, árvores e arbustos, sendo o restante constituído por lianas e epífitas. As espécies são amplamente distribuídas ocorrendo inclusive em ambientes costeiros de outras regiões brasileiras, como a região sudeste, assim como em ambientes não costeiros da Amazônia. Apenas duas espécies parecem ser exclusivamente costeiras, já outras espécies parecem ter preferência por ambientes de solo arenoso em geral. Diferentes associações de plantas são descritas e agrupadas em diferentes tipos de "formações vegetais" associadas à certos habitats, mas os dados da literatura não permitem identificar com precisão tais associações em toda a costa. Análises estatísticas mostraram que a distribuição das espécies ao longo da costa não apresentam nenhum padrão de agrupamento. Mudanças na composição da vegetação de restinga nas estações seca e chuvosa são mais provavelmente ligadas à variação do nível do lençol freático. As florestas de restinga são, em sua maioria, abertas e de pequeno porte. Entre as espécies arbóreas dominantes estão: Humiria balsamifera Aubl., Pouteria ramiflora (Mart.) Radlk., Anacardium occidentale L., Byrsonima crassifolia (L.) Kunth e Tapirira guianensis Aubl.

Palavras-chave - floresta costeira, planície arenosa costeira, vegetação de dunas

\section{Introduction}

The term restinga is commonly used in Brazil to describe the landscape forming on coastal sandy soils as well as the associated vegetation. More specifically, it is applied to sand bars forming between coastal lagoons and the ocean (Suguio 1992). For our discussion of northern Brazilian coastal vegetation, we follow Araújo \&

1. Universidade Federal do Pará, Campus Universitário do MarajóBreves, Conj. Bandeirante s/n, 68800-000 Breves, PA, Brazil.

2. Instituto de Estudos Costeiros, Universidade Federal do Pará, Campus de Bragança, Al. Leandro Ribeiro s/n, 68600-000 Bragança, PA, Brazil.

3. Museu Paraense Emilio Goeldi, Departamento de Botânica, Avenida Perimetral 1901, Terra Firme, 66000-000 Belém, PA, Brazil.

4. Autor para correspondência: moirah@ufpa.br
Henriques (1984), who characterize restinga vegetation as the complex of plant communities occurring on the quaternary sandy coastal plains of Brazil. Restinga vegetation includes herbaceous plant communities as well as assemblages dominated by shrubs or trees, with widely varying canopy coverage. Restinga vegetation colonizes chêniers, active or fixed dunes and dune valleys and is usually distinct from the neighbouring mangroves thriving on muddy sediments regularly inundated by the tides. Variety and composition of plant assemblages along the coastal plain depend on the local setting of marine and terrestrial environmental parameters (Alves et al. 2007). Restinga vegetation plays an ecologically important role in stabilizing active dunes by reducing the movement of sand (Pfadenhauer 1978, Tsoar \& Arens 2003). 
Restingas occur along approximately $70 \%$ of the Brazilian coastline (Guedes et al. 2006), which exceeds $8,000 \mathrm{~km}$ in length (Tessler \& Goya 2005). However, distribution of restinga areas is not continuous; they reach their greatest extensions (up to $700 \mathrm{~km}$ ) in Rio Grande do Sul State in southern Brazil (Villwock 1987 fide Araujo 2000).

Large areas of coastal vegetation suffer from human impacts, leading to degradation of beaches and dunes along the entire coast of Brazil (Scarano et al. 2004). Disorderly occupation of beaches along the Brazilian coast has caused loss of restinga vegetation cover (Scherer et al. 2005).

About $40 \%$ of the $1,500 \mathrm{~km}$-long coastline of the Amazon region belongs to the state of Pará (Suguio $\&$ Tessler 1984). Amazonian restingas are found sporadically on dune ridges and beaches between Marajó Bay (Pará) and São Marcos Bay (Maranhão) (Seeliger 1992). In Pará State, the greatest increase in human population has been recorded for the north-eastern coastal region (Szlafsztein 2003), where restinga areas are located. The state government of Pará is encouraging tourism as an additional source of income for the local population (Szlafstein \& Stern 2007). In this context, road infrastructure has been improved to facilitate tourist access to beach areas. Tourism is, however, restricted to a few sites (namely Marudá, Algodoal, Salinópolis and Ajuruteua) within the so-called Salgado Paraense (Prost $\&$ Rabelo 1996). Here and elsewhere, uncontrolled urban expansion as well as exploitation of illegal extraction sites for building materials (sand, loam) or unauthorized establishment of landfills has led to serious environmental problems within the protected coastal areas (Souza Filho 2001). In addition, wood cutting (Glaser et al. 2003, focussing on mangroves) and hunting (Pereira \& Alvez 2006) impose further threats to coastal vegetation and the associated fauna.

As destruction of this fragile ecosystem through human impacts increases at an accelerating pace (Bastos et al. 2001), gathering the existing information about restingas and intensifying corresponding research efforts are crucial steps towards their conservation and recovery. As a contribution towards this, we review the currently available literature on restinga vegetation of the coast of Pará and present an analysis of the current state of knowledge.

\section{Material and methods}

Data collection was based on articles published in scientific journals and books, conference proceedings with abstract collections, technical reports as well as graduate monographs, master's dissertations and doctoral studies. Studies were included if the respective study sites were located along the coast of the Brazilian state of Pará (between $0^{\circ} 42^{\prime} \mathrm{N}, 50^{\circ} 06^{\prime} \mathrm{W}$ and $1^{\circ} 00^{\prime} \mathrm{S}, 46^{\circ} 00^{\prime} \mathrm{W}$ ). In this region, the climate is warm throughout the year (annual mean air temperature about $26^{\circ} \mathrm{C}$, with minimum temperatures above $18^{\circ} \mathrm{C}$ ). Precipitation is seasonal with a perhumid rainy season between January and June. During the driest months (September to November), monthly precipitation is below $50 \mathrm{~mm}$. The annual precipitation average is about $2,500 \mathrm{~mm}$ (INMET 1992).

Plant species lists were checked for synonyms using taxonomic databases (IPNI 2008, Tropicos 2008) and checklists (Peterson et al. 2001, Zuloaga et al. 2003, Funk et al. 2007); taxonomic names from the analysed restinga articles were updated if necessary. The assignment of genera to angiosperm families follows APG II (Stevens 2001, APG 2003).

Based on the species lists obtained from the literature, the distribution and habitat preferences of selected woody species were investigated by analysing the respective information from the data base of the João Murça Pires Herbarium (MG) at the Emilio Goeldi Museum of Pará, Belém. To detect possible groupings among study sites, a dissimilarity matrix based on site-wise presence/absence lists of fully identified plant species was calculated. The applied dissimilarity measure was the Raup-Crick index (Raup \& Crick 1979) which is not sensitive to the number of species recorded at each site, thus reducing the influence of site-specific differences in sampling effort on the grouping procedure (e.g. Vellent et al. 2007). Grouping was then analysed by non-metric multidimensional scaling (NMDS). All calculations were performed with GNU R 2.8.1 (R Development Core Team 2008) with packages "vegan" (Oksanen et al. 2008) and "MASS" (Venables \& Ripley 2002).

\section{Results and discussion}

Study sites are shown in figure 1. The majority of the reviewed studies are abstracts published in conference proceedings $(42 \%$ of the total number of studies, $n=62$ ). Articles published in scientific journals account for $26 \%$, book chapters for $4 \%$ and doctoral, master's and graduate studies for 5, 10 and 10\%, respectively; technical reports account for another $8 \%$ of the reviewed studies. All consulted sources are in the Portuguese language.

The first to mention restinga vegetation in Pará was Pires (1973), who described it as "the vegetation growing on the white sand of the beaches and likewise on the dunes". He further mentions Anacardium occidentale L., Byrsonima crassifolia (L.) Kunth and Chrysobalanus icaco L. as typical constituents of restinga vegetation. 


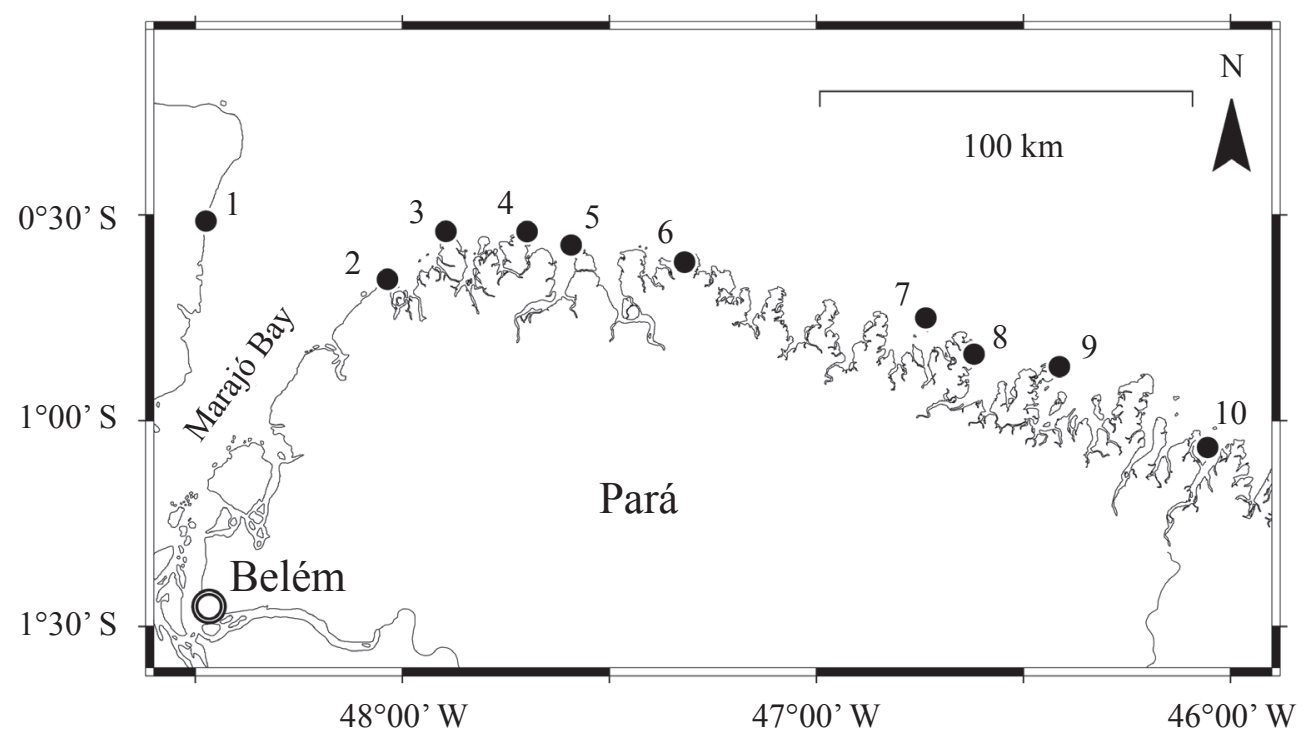

Figure 1. Restinga study sites along the coast of Pará State, Brazil (name of the corresponding administrative district in parentheses): 1. Bacurizal (Salvaterra). 2. Ilha Nova (São Caetano de Odivelas). 3. Ilha Romana (Curuça). 4. Crispim Beach (Marapanim). 5. Algodoal (Maracanã). 6. Atalaia (Salinópolis). 7. Ilha Canela (Bragança). 8. Vila Bonifácio (Bragança). 9. Urumajó (Augusto Corrêa). 10. Jabotitiua - Jatium (Viseu). Map based on the GMT coastline database (Wessel \& Smith 1996).

Later, Braga (1979) suggested a phytogeographical subdivision of the Amazon region, where he considered the restingas of Pará as poorly developed vegetation with low diversity. Studies specifically targeting restinga vegetation were first conducted in the 1980s around Algodoal beach (site 5 in figure 1; Bastos 1988, Santos \& Rosário 1988).

From the 90s onward, the number of studies focussing on restinga vegetation has increased but the more extensive studies concentrate on Algodoal, Crispim beach (site 4, figure 1) and Vila Bonifácio (site 8, figure 1). Studies conducted at these sites considered mainly floristic and phytosociological aspects of vascular plant formations (Algodoal: Bastos 1996, Crispim: CostaNeto et al. 1995, 2000, Amaral 1997, Costa-Neto 1999, Bonifácio: Silva et al. 2007, Santos 2008, Silva 2008). The species assemblages at the remaining sites within the study area were characterized by "rapid assessment"-type surveys (Lisboa et al. 1993, Amaral et al. 2001, Santos et al. 2001, Bastos et al. 2002). Amaral et al. (2008) present a check-list of species reported at 10 sites along the Brazilian Amazon coast but do not consider the more recent studies at Vila Bonifácio (Silva et al. 2007, Santos 2008, Silva 2008). A small number of studies provide local taxonomic keys for certain groups (Turneraceae: Vicente et al. 1999; Poaceae: Rocha et al. 2001a, b; Eriocaulaceae: Rocha \& Bastos 2004; Myrtaceae: Rosário et al. 2005; Fabaceae-Caesalpinioideae: Sousa
2008; Rubiaceae: Margalho 2008) or for all woody or herbaceous species found at a specific site (Amaral 1997, Costa-Neto 1999, Silva 2008).

Within the restinga landscape, authors differentiate between several plant formations; we use "formation" in the sense of an assemblage of plants visibly discernible from other assemblages by forming a distinctive structural pattern. Formations are associated with certain habitat types and may be characterized by a distinctive set of plant species. In denominating formations, the literature mainly follows Araújo \& Henriques (1984). The formations distinguished are: (1) halophile herbaceous salt-marsh vegetation subject to occasional tidal inundation (HSM); (2) psammophile herbaceous-rhizomatous vegetation of active dunes, possibly involved in dune build-up and fixation (HAD); (3) herbaceous dune valley vegetation (HDV; campo de dunas); (4) patches of woody vegetation within marshland (PWM; moitas, formação arbustiva aberta); (5) restinga forest (RF) of non-inundated areas such as paleodunes. It is assumed that the influence of tidal inundation and salt spray from the sea decreases from (1) to (5) but data on inundation frequency and soil pore water salinities are not available. Bastos (1996) and Amaral (1997) further identify a (salt-)marsh formation established behind fore-dunes next to the beach (brejo herbáceo, herbaceous swamp: HS). HSM is described for Crispim Beach only (Costa-Neto 1999) but it is possible that this formation was not clearly separated from other 
types of marsh vegetation by other authors. Occurrence of PWM was documented for Crispim and Algodoal (Amaral et al. 2008); the remaining formations have been observed along the entire coastline.

The total number of species reported for restingas from the coast of Pará amounts to 411, from 90 plant families (Amaral et al. 2008); the most intensively studied sites yielded the greatest number of species (273/77, 205/67 and 126/58 species/families at Algodoal, Crispim and Bonifácio, respectively; Bastos 1996, Amaral 1997, Amaral et al. 2008, Santos 2008, Silva 2008). The highest species richness was found in the Fabaceae family (53 species), followed by Poaceae (39), Cyperaceae (35), Rubiaceae (20) and Myrtaceae (19). Fabaceae (20) and Myrtaceae ( $\geq 17)$ featured the highest number of woody species (Bastos 1996, Amaral 1997, Silva 2008). Myrtaceae were important constituents of woody restinga vegetation, as in other parts of the country (Lemos et al. 2001, Araujo et al. 2004, Assis et al. 2004a; Assis et al. 2004b; Dornelles \& Waechter 2004, Scherer et al. 2005, Pimentel et al. 2007, Sacramento et al. 2007, Martins et al. 2008). Dominating genera in Myrtaceae are Eugenia ( $\geq 7$ species) and Myrcia (8). A special adaptation to restinga soils is attributed for example to Myrcia cuprea (O. Berg) Kiaersk. (Ferreira 2006).

Almost one half (48\%) of the plant species are predominantly herbaceous, whereas 1, 17 and 21\% are palms, trees and shrubs, respectively; the remaining species are lianas (11\%) and epiphytes (2\%).

Amaral (1997) was able to show that the number of tree and shrub species forming patches of woody vegetation within marsh (PWM) at Crispim increases with patch size (between 0.7 and $339 \mathrm{~m}^{2}$ ) from 4 to 39 , and that certain species do not occur when patch size is too small.

Overall species richness is low when compared to the southern Brazilian resting a flora (Rio de Janeiro State: 1005 species, Araújo 2000, Bertioga/São Paulo State: 611 species, Martins et al. 2008). High species richness of southern Brazilian restingas has been explained by their proximity (both in space and species composition) to the Atlantic rainforest (Araújo 2000, Scarano 2002). The relationship between restinga species from the Pará coast and the corresponding Amazonian rainforest species has not been analysed so far. Large variation in diversity can be expected, considering the differences in size and habitat diversity between the extensive restingas of southern Brazil and those considered here. Furthermore, both extension and habitat diversity may not be comparable among studies due to the individual researcher's decisions regarding the delimitation of the respective study area.

Table 1 shows a selection of those species reported from at least $50 \%$ of the reviewed sites with their respective habitats (Costa-Neto et al. 1995, 2000, Bastos 1996, Amaral 1997, Costa-Neto 1999, Amaral et al. 2008). It is evident that there is plenty of overlap between species assemblages assigned to the different habitat types. The occurrence of woody species within HS and HDV refers mostly to seedlings, which are usually unable to establish themselves permanently within the respective habitat (Bastos 1996), but may, within HDV, succeed to form patches of woody vegetation (PWM; Amaral 1997). Similarly, seedlings of mangrove tree species (Avicennia germinans (L.) L.,

Table 1. Herbaceous and woody restinga plant species from the coast of Pará and their respective habitat types. Listed are only species present at least in 5 of 10 reviewed study sites. (HSM $=$ herbaceous salt marsh; HAD $=$ herbaceous vegetation of active dunes; $\mathrm{HS}=$ herbaceous swamp; HDV = herbaceous dune valley vegetation; $\mathrm{PWM}=$ patches of woody vegetation within marshland; RF = restinga forest.) Species are listed in sequence of supposed ability to thrive under marine influence, derived from occupied habitat types and the corresponding distance to the sea.

Species

HSM HAD HS HDV PWM RF $\begin{gathered}\text { Sites } \\ \%\end{gathered}$

\footnotetext{
Herbaceous

Sesuvium portulacastrum (L.) L. Blutaparon portulacoides (A. St.-Hil.) Mears

Sporobolus virginicus (L.) Kunth Fimbristylis cymosa (Lam.) R. Br. Alternanthera tenella Colla Blutaparon vermiculare (L.) Mears Canavalia rosea (Sw.) DC.
}
Aizoaceae
Amaranthaceae
Poaceae
Cyperaceae
Amaranthaceae
Amaranthaceae
Fabaceae-Faboideae

90 


\begin{tabular}{|c|c|c|c|c|c|c|c|c|}
\hline Species & & HSM & HAD & HS & HDV & PWM & $\mathrm{RF}$ & $\begin{array}{l}\text { Sites } \\
\%\end{array}$ \\
\hline Fimbristylis spadicea (L.) Vahl & Cyperaceae & & • & • & & & & 90 \\
\hline Ipomoea pes-caprae (L.) R. Br. & Convolvulaceae & & • & $\bullet$ & & & & 100 \\
\hline Ipomoea imperati (Vahl) Griseb. & Convolvulaceae & & - & - & & & & 90 \\
\hline Vigna luteola (Jacq.) Benth. & Fabaceae-Faboideae & & • & • & & & & 60 \\
\hline Cassytha filiformis L. & Lauraceae & & • & $\bullet$ & $\bullet$ & & & 80 \\
\hline Cyperus ligularis L. & Cyperaceae & & - & - & - & & & 80 \\
\hline Paspalum vaginatum $\mathrm{Sw}$. & Poaceae & & - & - & - & & & 70 \\
\hline Ambrosia microcephala DC. & Asteraceae & & • & $\bullet$ & $\bullet$ & & & 70 \\
\hline Eclipta prostrata (L.) L. & Asteraceae & & - & - & - & & & 60 \\
\hline Sarcostemma clausum (Jacq.) Schult. & Apocynaceae-Asclepiadoideae & & - & - & - & & & 50 \\
\hline Centrosema brasilianum (L.) Benth. & Fabaceae-Faboideae & & • & • & $\bullet$ & • & - & 60 \\
\hline $\begin{array}{l}\text { Eleocharis geniculata (L.) Roem. \& } \\
\text { Schult. }\end{array}$ & Cyperaceae & & & $\bullet$ & • & & • & 80 \\
\hline Rhynchospora riparia (Nees) Boeck. & Cyperaceae & & & • & • & & & 70 \\
\hline Cyperus polystachyos Rottb. & Cyperaceae & & & - & • & & & 50 \\
\hline Scoparia dulcis L. & Plantaginaceae & & & • & • & & & 50 \\
\hline Stylosanthes angustifolia Vogel & Fabaceae-Faboideae & & & - & - & - & & 50 \\
\hline Ludwigia hyssopifolia (G. Don) Exell & Onagraceae & & & • & $\bullet$ & $\bullet$ & & 70 \\
\hline Desmodium barbatum (L.) Benth. \& Oerst. & Fabaceae-Faboideae & & & - & - & - & & 50 \\
\hline Comolia villosa (Aubl.) Triana & Melastomataceae & & & - & • & - & & 50 \\
\hline $\begin{array}{l}\text { Chamaecrista ramosa (Vogel) H.S. Irwin } \\
\& \text { Barneby }\end{array}$ & Fabaceae-"Caesalpinoideae" & & & & $\bullet$ & $\bullet$ & & 50 \\
\hline Crotalaria retusa $\mathrm{L}$. & Fabaceae-Faboideae & & & & $\bullet$ & & • & 60 \\
\hline Turnera melochioides A. St.-Hill. \& Camb. & Turneraceae & & & & - & & & 70 \\
\hline Cissus biformifolia Standl. & Vitaceae & & & & • & & & 70 \\
\hline $\begin{array}{l}\text { Cissus verticillata (L.) Nicolson \& C.E. } \\
\text { Jarvis }\end{array}$ & Vitaceae & & & & • & & & 70 \\
\hline \multicolumn{9}{|l|}{ Woody } \\
\hline Chrysobalanus icaco L. & Chrysobalanaceae & & - & - & - & - & - & 90 \\
\hline Entada polystachya (L.) DC. & Fabaceae-Mimosoideae & & & • & $\bullet$ & & & 60 \\
\hline Rhabdadenia biflora (Jacq.) Müll. Arg. & Apocynaceae & & & - & - & & & 50 \\
\hline Dalbergia ecastaphyllum (L.) Taub. & Fabaceae-Faboideae & & & $\bullet$ & & & & 90 \\
\hline Rhizophora mangle $\mathrm{L}$. & Rhizophoraceae & & & - & & - & & 50 \\
\hline Laguncularia racemosa (L.) C.F. Gaertn. & Combretaceae & & & - & & - & & 50 \\
\hline Conocarpus erectus $\mathrm{L}$. & Combretaceae & & & - & & - & & 50 \\
\hline Byrsonima crassifolia $\mathrm{L}$. & Malpighiaceae & & & - & & - & - & 50 \\
\hline Annona glabra $\mathrm{L}$. & Annonaceae & & & - & & & - & 70 \\
\hline Guettarda angelica Mart. ex Müll. Arg. & Rubiaceae & & & & $\bullet$ & & - & 60 \\
\hline Tapirira guianensis Aubl. & Anacardiaceae & & & & - & - & - & 70 \\
\hline Anacardium occidentale $\mathrm{L}$. & Anacardiaceae & & & & • & • & - & 90 \\
\hline Cassipourea guianensis Aubl. & Rhizophoraceae & & & & - & - & - & 50 \\
\hline Myrcia cuprea (O. Berg) Kiaersk. & Myrtaceae & & & & $\bullet$ & $\bullet$ & - & 70 \\
\hline Eugenia biflora (L.) DC. & Myrtaceae & & & & $\bullet$ & $\bullet$ & $\bullet$ & 50 \\
\hline Himatanthus articulatus (Vahl) Woodson & Apocynaceae & & & & - & - & - & 70 \\
\hline Vismia guianensis (Aubl.) Choisy & Clusiaceae & & & & • & $\bullet$ & - & 70 \\
\hline Clusia grandiflora Splitg. & Clusiaceae & & & & - & - & - & 60 \\
\hline $\begin{array}{l}\text { Licania octandra (Hoffmanns. ex Roem. } \\
\text { \& Schult.) Kuntze }\end{array}$ & Chrysobalanaceae & & & & $\bullet$ & • & • & 50 \\
\hline Copaifera martii Hayne & Fabaceae-"Caesalpinoideae" & & & & • & • & - & 60 \\
\hline Protium heptaphyllum (Aubl.) Marchand & Burseraceae & & & & - & • & - & 70 \\
\hline Pouteria ramiflora (Mart.) Radlk. & Sapotaceae & & & & & - & - & 50 \\
\hline Humiria balsamifera Aubl. & Humiriaceae & & & & & - & • & 50 \\
\hline Astrocaryum vulgare Mart. & Arecaceae & & & & & $\bullet$ & • & 60 \\
\hline
\end{tabular}


Acanthaceae-Avicennioideae; Laguncularia racemosa (L.) C. F. Gaertn., Combretaceae; Rhizophora mangle L., Rhizophoraceae) are reported in HS and PWM but do not develop to full size (Bastos 1996, Santos et al. 2001, Bastos et al. 2002).

A number of species are widespread and occur also in southern Brazilian restingas, for example the trees Anacardium occidentale (Anacardiaceae; Silva \& Oliveira 1989, Freire 1990, Freire \& Monteiro 1993, Matias \& Nunes 2001, Pereira \& Alvez 2006, Queiroz 2007), Guapira opposita (Vell.) Reitz (Nyctaginaceae; Silva \& Oliveira 1989, Danilevicz et al. 1990, Rossoni \& Batista 1994, Menezes \& Araujo 1999, Lemos et al. 2001, Moreto \& Mondin 2002, Sá 2002, Sztutman \& Rodrigues 2002, Dornelles \& Waechter 2004, Batista et al. 2005, Neto et al. 2005, Scherer et al. 2005, Sonehara 2005, Klein et al. 2007, Pimentel et al. 2007, Martins et al. 2008) and Protium heptaphyllum (Aubl.) Marchand (Burseraceae; Silva \& Oliveira 1989, Assumpção \& Nascimento 2000, Pereira \& Alvez 2006, Leite et al. 2007, Pimentel et al. 2007, Sacramento et al. 2007). These species are, however, not restricted to restinga habitats. Other common woody restinga species in Pará are Chrysobalanus icaco (Chrysobalanaceae), Humiria balsamifera Aubl. (Humiriaceae) and Byrsonima crassifolia (Malpighiaceae). B. crassifolia is not reported from southeast and southern Brazil, where $B$. sericea DC. is common (Assumpção \& Nascimento 2000, Menezes \& Araujo 2004, Matallana et al. 2005, Pereira \& Alvez 2006, Sacramento et al. 2007).

An analysis of the João Murça Pires Herbarium specimen data base shows that in Pará the only woody restinga species restricted to the coastal zone are Coccoloba ramosissima Wedd. (Polygonaceae), the aforementioned Myrcia cuprea (Myrtaceae) and the Sapindaceae Dodonaea viscosa Jacq. The latter species is, however, widespread and not restricted to the coastal region elsewhere. D. viscosa is not a typical lowland rainforest tree, and it may be that collectors in Pará so far neglected, e.g., open and anthropogenically influenced areas, resulting in a biased view of $D$. viscosa's distribution in this region. It proved difficult to ascertain whether species were restricted to inland sites e.g. to sandy soils, as such information is often omitted from herbarium labels. However, occurrence on sandy soils and in campina or campinarana (open shrub on poor sandy soils and white sand forest, respectively) environments was mentioned for a number of species (3-23\% of non-restinga vouchers for the woody species listed in table 1).

Among the herbaceous plants, Ambrosia microcephala DC. (Asteraceae) is cited as the only species restricted to restinga vegetation of northern Brazil (Freire \& Monteiro 1993, Costa-Neto 1999). Widespread along the coast of Brazil (and other tropical coasts) are the HAD/HSM species Sesuvium portulacastrum (L.) L. (Aizoaceae), Ipomoea pes-caprae (L.) R. Br. (Convolvulaceae), Sporobolus virginicus (L.) Kunth (Poaceae) and Blutaparon portulacoides (A. St.-Hil.) Mears (Amaranthaceae), which are considered to be an important stabilizer of active dunes (Pfadenhauer 1978, Cordazzo 1985, Costa-Neto 1999).

It was not possible within the scope of this review, to verify the identification of species by consulting all original collections deposited in the local herbaria MG and IAN (both in Belém, Brazil). A small number of corrections of previous misidentifications discussed by Rocha et al. (2001a, b) and Margalho (2008) are silently applied in table 1. Due to the less taxonomically motivated character of most studies, there may be more cases of overlooked or incorrectly identified species. For example, Clusia palmicida Rich. ex Planch. \& Triana (Clusiaceae) has so far been reported only from Bonifácio (Silva 2008); it is probably more widespread but may not have been noted as it is easily mistaken for C. grandiflora Splitg. (J. B. F. Silva, unpublished data).

Non-metric multidimensional scaling with presence-absence data of plant species did not yield a distinct grouping of sites (figure 2); possible divisions exist among sites of the Bragança-Viseu basin (sites 7-10 in figure 1) on one hand, localities around Marajó Bay (sites 1-3 in figure 1) on the other and then the remaining, loosely associated sites Salinópolis, Crispim and Algodoal (4-6 in figure 1). Additional field work is needed to confirm the existence of such a regional pattern. Hierarchical clustering based on a Bray-Curtis (= Czekanowski/Sørensen) dissimilarity matrix for a similar data set presented by Amaral et al. (2008) shows a close association between the well-sampled sites Algodoal and Crispim and non-conclusive grouping of the other localities.

It can be expected that the seasonal precipitation regime of the study region induces dominance shifts in plant communities. Bastos (1996) documented by means of wells that the ground water table at Algodoal sunk during the dry season by 2.6, 2.9, 1.5 and $1.4 \mathrm{~m}$ in comparison to the local wet season maximum in HAD, PWM, HDV and HS formations, respectively; her HDV and HS wells were covered by 0.1 and $0.7 \mathrm{~m}$ of surface water during the rainy season, respectively (included in the figures given above). Bastos (1996) noted corresponding changes in the composition of the 


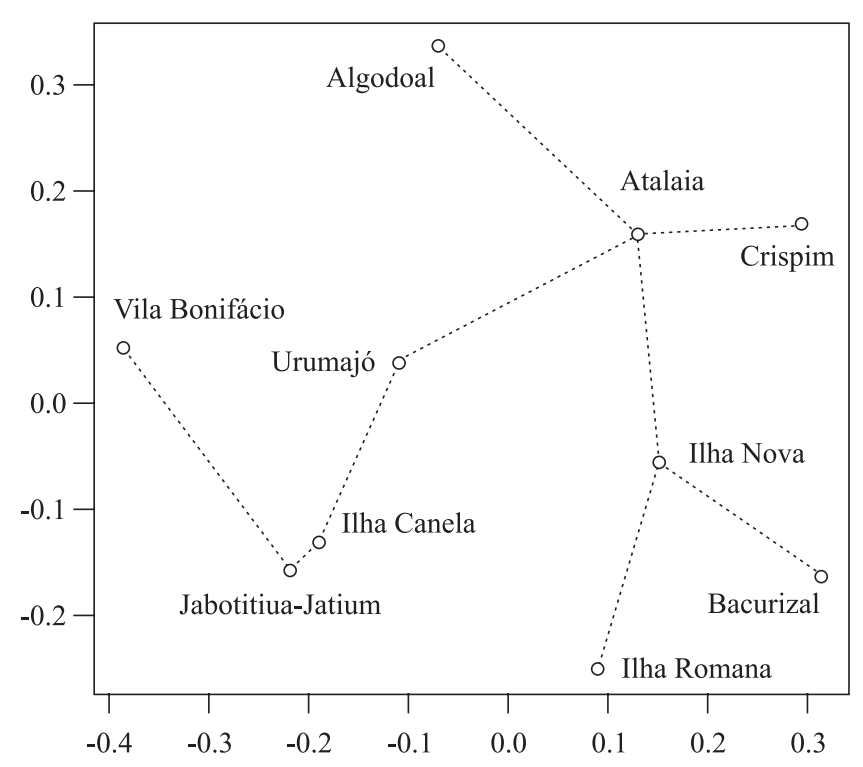

Figure 2. Non-metric multidimensional scaling (NMDS) of restinga sites along the coast of Pará (Raup-Crick dissimilarity matrix based on occurrence of plant species; $\mathrm{R}^{2}$ for non-metric fit between observed rank dissimilarities and ordination distance: 0.99). Dotted lines show the minimum spanning tree among sites derived from NMDS results.

herbaceous vegetation, resulting in a reduced number of species during the dry season. The same author observed a reduction of vegetation cover during the dry season along with leaf fall in the persisting plants, both indicators of reduced water availability. Elevation profiles for Algodoal and Bonifácio (Bastos 1996, Silva 2008) show that most woody constituents of restinga vegetation were restricted to stabilised, elevated dune regions not reached by tidal inundation; structural development and species richness increased with distance from the sea (Bastos 1996).
Bastos (1996), Amaral (1997) and Silva (2008) provided data on structural properties of woody vegetation at Algodoal, Crispim and Bonifácio, respectively. Bastos (1996) considered trees and shrubs with breast height stem diameters $\geq 1.6 \mathrm{~cm}$. Amaral (1997) and Silva (2008) measured the stem diameter at ground level, Amaral (1997) including all woody plants and Silva (2008) only those $\geq 2.5 \mathrm{~cm}$ (measured within the cylindrical stem section next to the soil surface). Coverage/basal area of woody vegetation was reported by all authors as projected stem area (at breast height or basal) per unit of ground area. Amaral (1997) and Silva (2008) observed that a great number of stems show prostrate growth, and that, as a consequence, stem length often exceeds actual crown height. Pouteria ramiflora, Anacardium occidentale and Humiria balsamifera were among the largest trees at Bonifácio, with maximum/average basal stem diameters of $32 / 8,25 / 12$ and $29 / 16 \mathrm{~cm}$, respectively (Silva 2008); even larger specimens of $H$. balsamifera with basal diameter $>80 \mathrm{~cm}$ were observed at Bonifácio outside Silva's sampling plots (R. M. Silva, U. Mehlig and L. O. Santos, unpublished data). However, the latter species lagged behind the more abundant $P$. ramiflora, A. occidentale and Byrsonima crassifolia in terms of average basal area $\left(3.3,1.8,1.2\right.$ and $1.1 \mathrm{~m}^{2} \mathrm{ha}^{-1}$, respectively; Silva 2008). Amaral (1997) and Bastos (1996) do not report average and maximum diameters of single species; at Crispim, H. balsamifera is the species with the highest basal area $\left(5.7 \mathrm{~m}^{2}\right.$ ha-1) within the larger patches of woody vegetation. Interestingly, $H$. balsamifera was not found by Bastos (1996) at Algodoal, where Byrsonima crassifolia (in PWM) and Tapirira guianensis (in RF) reach the highest basal areas ( 0.9 and $2.0 \mathrm{~m}^{2} \mathrm{ha}^{-1}$, respectively). A summary of forest structure data is given in table 2 .

Table 2. Forest structure data from Algodoal, Crispim, and Bonifácio, coast of Pará State, Brazil. Sampling area refers only to the plots where forest structure data were collected; floristic data were also recorded outside of these plots. Bastos (1996) used a minimum breast height diameter of $1.6 \mathrm{~cm}$, Silva (2008) a minimum ground level diameter of $2.5 \mathrm{~cm}$; to facilitate comparison, data of Amaral (1997; no minimum diameter) are presented for basal diameters $\geq 2.5 \mathrm{~cm}$ (obtained by interpolation from his histograms).

\begin{tabular}{lcccccc}
\hline Site & $\begin{array}{c}\text { Sampling área } \\
\text { (ha) }\end{array}$ & $\begin{array}{c}\text { Density } \\
\left(\text { indiv. ha }^{-1}\right)\end{array}$ & $\begin{array}{c}\text { Basal área } \\
\left(\mathrm{m}^{2} \mathrm{ha}^{-1}\right)\end{array}$ & $\begin{array}{c}\text { Height max. } \\
(\mathrm{m})\end{array}$ & $\begin{array}{c}\text { Diameter max. } \\
(\mathrm{cm})\end{array}$ & $\begin{array}{c}\text { Diameter mean } \\
(\mathrm{cm})\end{array}$ \\
\hline Algodoal (Bastos 1996) & 0.50 & $1,669^{*}$ & 16.2 & 10 & 24.5 & 4.6 \\
& 0.05 & $6,060^{* *}$ & & & & $>45.3$ \\
Crispim (Amaral 1997) & 0.32 & $1,581^{*}$ to 6,023 & 15.4 & 8 & 25 & - \\
Bonifácio (Silva 2008) & 0.46 & $2,293^{* *}$ & 9.9 & 8 & 5.5 \\
\hline
\end{tabular}

$*=$ calculated for patches of woody vegetation, excluding open areas; $* *=$ resting $a$ forest. 
The restinga vegetation of Pará is, as far as is known, rather poor compared to the more abundant flora of the sandy coastal plains of southeastern Brazil. This is probably due to the less extensive restinga areas in Amazonia. While a few species are specialists for coastal environments, the majority of taxa also occurs at sites distant from the sea; however, a number of species seem to prefer sandy soils in the hinterland, as well. No endemic species are known and no clear pattern emerges in respect to the grouping of restinga plant communities along the coast of Pará. The currently applied terminology for plant formations is not satisfactory; transitions between the different environments have to be analysed ever more carefully, and drastic seasonal changes in the species composition of herbaceous communities are not covered by the superficial classification "formations" provide. A more precise description of plant communities is necessary as a starting point for further ecological studies as well as for specifying conservation and management strategies. Future research should not only try to identify the plant associations and their set of characteristic species within the different restinga habitats, but also focus on the environmental parameters that may determine the occurrence of each plant association.

Acknowledgements - R. M. Silva is grateful for the fellowship granted by the Conselho Nacional de Desenvolvimento Científico e Tecnológico (CNPq). Financial support was partially provided by the Program PROINT/UFPA 20062007 and MCT/CNPq 06/2006 CT-Amazonia (process \#553306/2006-5). We thank two anonymous reviewers for helpful comments and Dr. C. R. Beasley for improving the English of the manuscript.

\section{References}

ALVES, R.J.V., CARDIN, L. \& KROPF, M.S. 2007. Angiosperm disjunction "Campos rupestres-restingas": a re-evaluation. Acta Botanica Brasilica 21:675-685.

AMARAL, D.D. 1997. Contribuição ao estudo das Formações Abertas de Moitas do litoral paraense, restinga do Crispim, município de Marapanim-PA. Dissertação de mestrado, Universidade Rural do Pará/Museu Paraense Emilio Goeldi, Belém.

AMARAL, D.D., SANTOS, J.U.M., BASTOS, M.N.C. \& COSTA, D.C.T. 2001. A vegetação da Ilha Canela, município de Bragança, Pará, Brasil. Boletim do Museu Paraense Emilio Goeldi 17:389-402.

AMARAL, D.D., PROST, M.T., BASTOS, M.N.C., COSTANETO, S.V. \& SANTOS, J.U.M. 2008. Restingas do litoral amazônico, estados do Pará e Amapá, Brasil. Boletim do Museu Paraense Emilio Goeldi série Ciências Naturais 3:35-67.
APG II. 2003. An update of the Angiosperm Phylogeny Group classification for the orders and families of flowering plants: APG II. Botanical Journal of the Linnean Society 141:399-436.

ARAUJO, D.S.D. 2000. Análise florística e fitogeográfica das restingas do Estado do Rio de Janeiro. Tese de doutorado, Universidade Federal do Rio de Janeiro, Rio de Janeiro.

ARAUJO, D.S.D. \& HENRIQUES, R.P.B. 1984. Análise florística das restingas do Rio de Janeiro. In Restingas: origem, estruturas e processos (L.D.L. Lacerda, D.S.D. Araujo, R. Cerqueira \& B. Turcq, eds.). CEUFF, Niterói, p.159-193.

ARAUJO, D.S.D., PEREIRA, M.C.A. \& PIMENTEL, M.C.P. 2004. Flora e estrutura de comunidades na restinga de Jurubatiba - Síntese dos conhecimentos com enfoque especial para a formação aberta de Clusia. In Pesquisas de longa duração na restinga de Jurubatiba: ecologia, história natural e conservação (C.F.D. Rocha, F.A. Esteves \& F.R. Scarano, eds.). RiMa, São Carlos, p.59-76.

ASSIS, A.M., THOMAZ, L.D. \& PEREIRA, O.J. 2004a. Florística de um trecho de floresta de restinga no município de Guarapari, Espírito Santo, Brasil. Acta Botanica Brasilica 18:191-201.

ASSIS, A.M., PEREIRA, O.J. \& THOMAZ, L.D. 2004b. Fitossociologia de uma floresta de restinga no Parque Estadual Paulo César Vinha, Setiba, município de Guarapari (ES). Revista Brasileira de Botânica 27:349361.

ASSUMPÇÃO, J. \& NASCIMENTO, M.T. 2000. Estrutura e composição florística de quatro formações vegetais de restinga no complexo lagunar Grussaí/Iquipari, São João da Barra, RJ, Brasil. Acta Botanica Brasilica 14:301315.

BASTOS, M.N.C. 1988. Levantamento florístico em restinga arenosa litorânea na ilha de Maiandeua - PA. Boletim do Museu Paraense Emilio Goeldi 4: 159-173.

BASTOS, M.N.C. 1996. Caracterização das formações vegetais da restinga da Princesa, Ilha de Algodoal - PA. Tese de doutorado, Universidade Federal do Pará/Museu Paraense Emilio Goeldi, Belém.

BASTOS, M.N.C., SANTOS, J.U.M., AMARAL, D.D. \& COSTA-NETO, S.V. 2001. Alterações ambientais na vegetação litorânea do nordeste do Pará. In Ecossistemas costeiros: impactos e gestão ambiental (M.T. Prost \& A.C. Mendes, eds.). Museu Paraense Emilio Goeldi/ Secretaria de Estado de Ciência, Tecnologia e Meio Ambiente, Belém, p.26-38.

BASTOS, M.N.C., AMARAL, D.D., COSTA, D.C.T., SANTOS, J.U.M. \& ROSA JÚNIOR, W.O. 2002. Fitofisionomia da APA da costa do Urumajó, município de Augusto Corrêa-Pará. In Anais do VI Workshop Ecolab (CD ROM). p.1-11. 
BATISTA, T.L., CANTEIRO, R.C.A., DORNELES, L.P.P. \& COLARES, I.G. 2005. Levantamento florístico das comunidades vegetais na Área de Proteção Ambiental da Lagoa Verde, Rio Grande, RS. Revista Brasileira de Biociências 5:225-227.

BRAGA, P.I.S. 1979. Subdivisão fitogeográfica, tipos de vegetação, conservação e inventário florístico da floresta amazônica. Acta Amazonica 9:53-80.

CORDAZZO, C.V. 1985. Taxonomia e ecologia da vegetação das dunas costeiras ao sul de Cassino (RS). Tese de mestrado, Universidade Federal do Rio Grande do Sul, Rio Grande.

COSTA-NETO, S.V. 1999. As formações herbáceas da restinga do Crispim, Marapanim-PA. Tese de mestrado, Universidade Federal Rural da Amazônia/Museu Paraense Emilio Goeldi, Belém.

COSTA-NETO, S.V., BASTOS, M.N.C. \& LOBATO, L.C.B. 1995. Composição florística e fitofisionomia da restinga do Crispim, Município de Marapanim, PA. Boletim do Museu Paraense Emilio Goeldi série Botânica 12:237249.

COSTA NETO, S.V., SANTOS, J.U.M., BASTOS, M.N.C., AMARAL, D.D. \& LOBATO, L.C.B. 2000. Composição florística das formações herbáceas da restinga do Crispim-Marapanim-Pará. Boletim do Museu Paraense Emilio Goeldi série Botanica 16:173-222.

DANILEVICZ, E., JANKE, H. \& PANKOWSKI, L.H.S. 1990. Florística e estrutura da comunidade herbácea e arbustiva da Praia do Ferrugem, Garopaba, SC. Acta Botanica Brasilica 4:21-34.

DORNELES,L.P.P.\&WAECHTER, J.L. 2004.Fitossociologia do componente arbóreo na floresta turfosa do Parque Nacional da Lagoa do Peixe, Rio Grande do Sul, Brasil. Acta Botanica Brasilica 18:815-824.

FERREIRA, N.M.M. 2006. Germinação de sementes e morfologia de plântulas de espécies de restinga com potencial paisagístico. Tese de mestrado, Universidade Federal Rural da Amazônia/Museu Paraense Emilio Goeldi, Belém.

FREIRE, M.S.B. 1990. Levantamento florístico do Parque Estadual das Dunas de Natal. Acta Botanica Brasilica 4:41-59.

FREIRE, M.C.C.M. \& MONTEIRO, R. 1993. Florística das praias da Ilha de São Luís, Estado do Maranhão (Brasil): diversidade de espécies e suas ocorrências no litoral brasileiro. Acta Amazonica 23:125-140.

FUNK, V., HOLLOWELL, T., BERRY, P., KELLOFF, C. \& ALEXANDER, S.N. 2007. Checklist of the plants of the Guiana Shield (Venezuela: Amazonas, Bolivar, Delta Amacuro; Guyana, Surinam, French Guiana). Contributions from the United States National Herbarium 55:1-584.

GLASER, M., BERGER, U. \& MACEDO, R. 2003. Local vulnerability as an advantage: mangrove forest management in Pará State, north Brazil, under conditions of illegality. Regional Environmental Change 3:162-172.
GUEDES, D., BARBOSA, L.M. \& MARTINS, S.E. 2006. Composição florística e estrutura fitossociológica de dois fragmentos de floresta de restinga no Município de Bertioga, SP, Brasil. Acta Botanica Brasilica 20:299-311.

INMET. 1992. Normas climatológicas (1961-1990). Instituto Nacional de Meteorologia, Brasília.

IPNI. 2008. The International Plant Names Index. Royal Botanic Gardens, Kew; Harvard University Herbaria; Australian National Herbarium, Kew/Cambridge-MA/ Canberra. http://www.ipni.org (accessed 2008 Mar 1).

KLEIN, A.S., CITADINI-ZANETTE, V. \& SANTOS, R. 2007. Florística e estrutura comunitária da restinga herbácea no município de Araranguá, Santa Catarina. Biotemas 20:15-26.

LEITE, V.R., LOPES, T.S. \& PEREIRA, O.J. 2007. Florística do ecótono floresta de restinga e mata atlântica de tabuleiro no município da Serra (ES). Revista Brasileira de Biociências 5:483-485.

LEMOS, M.C., PELLENS, R. \& LEMOS, L.C. 2001. Perfil e florística de dois trechos de Mata Litorânea no Município de Maricá-RJ. Acta Botanica Brasilica 15:321-334.

LISBOA, P.L.B., LISBOA, R.C., ROSA, N.A. \& SANTOS, M.R. 1993. Padrões de diversidade florística na reserva ecológica de Bacurizal, em Salvaterra, ilha do Marajó, Pará. Boletim do Museu Paraense Emilio Goeldi 9:223248.

MARGALHO, L.F. 2008. Flórula fanerogâmica das restingas do Estado do Pará. APA de Algodoal/Maiandeua, Maracanã - PA: Rubiaceae Juss. Tese de mestrado, Universidade Federal Rural da Amazônia/Museu Paraense Emilio Goeldi, Belém.

MARTINS, S.E., ROSSI, L., SAMPAIO, P.S.P. \& MAGENTA, M.A.G. 2008. Caracterização florística de comunidades vegetais de restinga em Bertioga, SP, Brasil. Acta Botanica Brasilica 22:249-274.

MATALlANA, G., WENDT, T., ARAUJO, D.S.D. \& SCARANO, F.R. 2005. High abundance of dioecious plants in a tropical coastal vegetation. American Journal of Botany 92:1513-1519.

MATIAS, L.Q. \& NUNES, E.P. 2001. Levantamento florístico da Área de Proteção Ambiental de Jericoacara, Ceará. Acta Botanica Brasilica 15:35-43.

MENEZES, L.F.T. \& ARAUJO, D.S.D. 1999. Estrutura de duas formações vegetais do cordão externo da restinga de Marambaia, RJ. Acta Botanica Brasilica 13:223-235.

MENEZES, L.F.T. \& ARAUJO, D.S.D. 2004. Regeneração e riqueza da formação arbustiva de Palmae em uma cronoseqüência pós-fogo na restinga da Marambaia, Rio de Janeiro, RJ, Brasil. Acta Botanica Brasilica 18:771-780.

MORETO, F. \& MONDIN, C.A. 2002. Levantamento qualiquantitativo do componente lenhoso do subosque de uma Mata Arenosa de Restinga no Balneário Quintão, Palmares do Sul, Rio Grande do Sul. Pesquisas (Botânica) 52:111-123. 
NETO, J.A.A.M., SOUZA, A.L., LANA, J.M. \& VELENTE, G.E. 2005. Composição florística, espectro biológico e fitofisionomia da vegetação de Muçununga nos municípios de Caravelas e Mucuri, Bahia. Revista Árvore 29:139-150.

OKSANEN, J., KINDT, R., LEGENDRE, P., O'HARA, B., SIMPSON, G.L., SOLYMOS, P., STEVENS, M.H.H. \& WAGNER, H. 2008. vegan: Community Ecology Package, version 1.15-0. University of Oulu (and others), Oulu, Finland. http://vegan.r-forge.r-project.org (accessed 2008 Dec 16).

PEREIRA, M.S. \& ALVEZ, R.R.N. 2006. Composição florísitica de um remanescente de Mata atlântica na Área de Proteção Ambiental Barra do Rio Mamanguape, Paraíba, Brasil. Revista de Biologia e Ciências da Terra 6:357-366.

PETERSON, P.M., SORENG, R.J., DAVIDS, E.G, FILGUEIRAS, T.S., ZULOAGA, F.O. \& JUDZIEWICZ, E.J. 2001. Catalogue of New World grasses (Poaceae): II. subfamily Chloridoideae. Contributions from the United States National Herbarium 41:1-255.

PFADENHAUER, J. 1978. Contribuição ao conhecimento da vegetação e de suas condições de crescimento nas dunas costeiras do Rio Grande do Sul, Brasil. Revista Brasileira de Biologia 38:827-836.

PIMENTEL, M.C.P., BARROS, M.J., CIRNE, P., MATTOS, E.A., OLIVEIRA, R.C., PEREIRA, M.C.A., SCARANO, R.R., ZALUAR, H.L.T. \& ARAÚJO, D.S.D. 2007. Spatial variation in the structure and floristic composition of "restinga" vegetation in southeastern Brazil. Revista Brasileira de Botânica 30: 543-551.

PIRES, J.M. 1973. Tipos de vegetação da Amazônia. Publicações Avulsas do Museu Paraense Emilio Goeldi 20:179-202.

PROST, M.T.R.C. \& RABELO, B.V. 1996. Variabilidade fitoespacial de manguezais litorâneos e dinâmica costeira: exemplos da Guyana Francesa, Amapá e Pará. Boletim do Museu Paraense Emilio Goeldi série Ciências da Terra 8:101-121.

QUEIROZ, E.P. 2007. Levantamento florístico e georreferenciamento das espécies com potencial econômico e ecológico em restinga de Mata de São João, Bahia, Brasil. Biotemas 20:41-47.

R DEVELOPMENT CORE TEAM. 2008. R: a language and environment for statistical computing. R Foundation for Statistical Computing, Vienna, Austria. http://www.Rproject.org (accessed 2008 Dec 16).

RAUP, D.M. \& CRICK, R.E. 1979. Measurement of faunal similarity in palaeontology. Journal of Paleontology 53:1213-1227.

ROCHA, A.E.S. \& BASTOS, M.N.C. 2004. Flora fanerogâmica das restingas do Pará. APA de AlgodoalMaiandeua. II - Eriocaulaceae P. Beauv. ex Desv. Hoehnea 31:103-111.
ROCHA, A.E.S., BASTOS, M.N.C. \& SANTOS, J.U.M. 2001a. O gênero Paspalum L. (Gramineae/Poaceae) na restinga da Praia da Princesa, APA de Algodoal/ Maiandeua, Maracanã, Pará, Brasil. Boletim do Museu Paraense Emilio Goeldi série Botânica 17:187-207.

ROCHA, A.E.S., BASTOS, M.N.C. \& SECCO, R.S. 2001 b. O gênero Panicum L. (Gramineae/Poaceae) na restinga da Praia da Princesa, APA de Algodoal/Maiandeua, Maracanã, Pará. Boletim do Museu Paraense Emilio Goeldi série Botânica 17:297-314.

ROSÁRIO, A.S., SECCO, R.S., AMARAL, D.D., SANTOS, J.U.M. \& BASTOS, M.N.C. 2005. Flórula fanerogâmica das restingas do estado do Pará. Ilhas de Algodoal e Maiandeua - 2. Myrtaceae A. L. de Jussieu. Boletim do Museu Paraense Emilio Goeldi série Botânica 1:31-48.

ROSSONI, M.G. \& BAPTISTA, L.R.M. 1994. Composição florística da mata de restinga, Balneário Rondinha Velha, Arroio do Sal, RS, Brasil. Pesquisas (Botânica) 45:115-131.

SÁ, C.F.C. 2002. Regeneração de um trecho de floresta de restinga na Reserva Ecológica de Jacarepiá, Saquarema, Estado do Rio de Janeiro: II Estrato arbustivo. Rodriguésia 53:5-23.

SACRAMENTO, A.C., ZICKEL, C.S. \& ALMEIDAJUNIOR, E.B. 2007. Aspectos florísticos da vegetação de restinga no litoral de Pernambuco. Revista Árvore 31:1121-1130.

SANTOS, L.O. 2008. Estudo da vegetação do ecótono campo-mata de restinga e de terra firme na península de Ajuruteua, Bragança, Pará. Trabalho de conclusão de curso, Universidade Federal do Pará, Campus Bragança, Bragança.

SANTOS, J.U.M. \& ROSÁRIO, C.S. 1988. Levantamento da vegetação fixadora de dunas de Algodoal - PA. Boletim do Museu Paraense Emilio Goeldi 4:133-151.

SANTOS, J.U.M., AMARAL, D.D., BASTOS, M.N.C., SECCO, R.S., COSTA-NETO, S.V. \& COSTA, D.C.T. 2001. Vegetação da área de proteção ambiental Jabotitiua-Jatium, município de Viseu, Pará, Brasil. Acta Amazonica 33:431-444.

SCARANO, F.R. 2002. Structure, function and floristic relationships of plant communities in stressful habitats marginal to the Brazilian Atlantic rain forest. Annals of Botany 90:517-524.

SCARANO, F.R., CIRNE, P., NASCIMENTO, M.T., SAMPAIO, M.C., VILLELA, D.M., WENDT, T. \& ZALUAR, H.L.T. 2004. Ecologia vegetal: integrando ecossistema, comunidades, populações e organismos. In Pesquisas de longa duração na restinga de Jurubatiba: ecologia, história natural e conservação (C.F.D. Rocha, F.A. Esteves \& F.R. Scarano, eds.). RiMa, São Carlos, p.77-97.

SCHERER, A., MARASCHIN-SILVA, F. \& BAPTISTA, R.L. M. 2005. Florística e estrutura do componente arbóreo de matas de restinga arenosa no Parque Estadual de Itapuã, RS, Brasil. Acta Botanica Brasilica 19:717-726. 
SEELIGER, U. 1992. Coastal foredunes of southern Brazil: physiography, habitats and vegetation. In Coastal plant communities of Latin America (U. Seeliger, ed.). Springer, New York, p.367-381.

SILVA, J.G. \& OLIVEIRA, A.S.A. 1989. Vegetação de restinga no município de Maricá, RJ. Acta Botanica Brasilica 3:253-272.

SILVA, R.M. 2008. Taxonomia e fitossociologia da vegetação arbustivo-arbórea de dunas na restinga da Vila Bonifácio, península de Ajuruteua, Bragança, Pará. Tese de mestrado, Universidade Federal Rural da Amazônia/Museu Paraense Emilio Goeldi, Belém.

SILVA, R.M., MENEZES, M.P.M., MEHLIG, U., SANTOS, C.C.L. \& PEREIRA, M.V.S. 2007. Fitofisionomia da restinga da Vila Bonifácio, Península de Ajuruteua, Bragança, Pará, Brasil. In Ecolab - Ecossistemas costeiros amazônicos - Boletim de Resumos Expandidos. p.310-314.

SONEHARA, J.S. 2005. Aspectos florísticos e fitossociológicos de um trecho de vegetação de restinga no Parque Estadual do Rio da Onça-Matinhos, PR. Tese de mestrado, Universidade Federal do Paraná, Curitiba.

SOUSA, J.S. 2008. Flórula fanerogâmica das restingas do Estado do Pará: Leguminosae-Mimosoideae. Tese de mestrado, Universidade Federal Rural da Amazônia/ Museu Paraense Emilio Goeldi, Belém.

SOUZA FILHO, P.W.M. 2001. Impactos naturais e antrópicos na planície costeira de Bragança. In Ecossistemas costeiros: impactos e gestão ambiental (M.T. Prost \& A.C. Mendes, eds.). Museu Paraense Emilio Goeldi/ Secretaria de Estado de Ciência, Tecnologia e Meio Ambiente, Belém, p.133-144.

STEVENS, P.F. 2001. Angiosperm Phylogeny Website, Version 9. Missouri Botanical Garden, St. Louis. http:// www.mobot.org/MOBOT/research/APweb (accessed 2008 Nov).

SUGUIO, K. 1992. Dicionário de geologia marinha. T. A. Queiroz, São Paulo.

SUGUIO, K. \& TESSLER, M.G. 1984. Planícies de cordões arenosos litorâneos quaternários do Brasil: origem e nomenclatura. In Restingas: origem, estrutura e processos (L.D. Lacerda, D.S.D. Araujo, R. Cerqueira \& B. Turcq, eds.). CEUFF, Niterói, p.453-458.

SZLAFSZTEIN, C. 2003. Vulnerability and response measures to natural hazard and sea level rise impacts: long-term coastal zone management, NE of the state of Pará, Brazil. ZMT Contributions 17. Center for Marine Tropical Ecology (ZMT), Bremen.
SZLAFSZTEIN, C. \& STERR, H. 2007. A GIS-based vulnerability assessment of coastal natural hazards, state of Pará, Brazil. Journal of Coastal Conservation 11:53-66.

SZTUTMAN, M. \& RODRIGUES, R.R. 2002. O mosaico vegetacional em uma área de floresta contínua da planícies litorânea, Parque Estadual da Campina do Encantado, Pariquera-Açu, SP. Revista Brasileira de Botânica 25:161-176.

TESSLER, M.G. \& GOYA, S.C. 2005. Processos costeiros condicionantes do Litoral Brasileiro. Revista do Departamento de Geografia 17:11-23.

TROPICOS. 2008. Tropicos.org. Missouri Botanical Garden, St. Louis. http://www.tropicos.org (accessed 2008 Dec 16).

TSOAR, H.\&ARENS, S.M. 2003. Mobilização e estabilização de dunas em climas úmidos e secos. Revista de Geografia da Universidade Federal do Ceará 3:131-144.

VENABLES, W.N. \& RIPLEY, B.D. 2002. Modern applied statistics with S. $4^{\text {th }}$ ed. Springer, New York.

VELLENT, M., VERHEYEN, K., FLINN, K.M., JACQUEMYN, H., KOLB, A., CALSTER, H.V., PETERKEN, G., GRAAE, B.J., BELLEMARE, J., HONNAY, O., BRUNET, J., WULF, M., GERHARDT, F. \& HERMY, M. 2007. Homogenization of forest plant communities and weakening of species-environment relationships via agricultural land use. Journal of Ecology 95:565-573.

VICENTE, A.C.A., MACEDO, E.G., SANTOS, J.U.M., POTIGUARA, R.C.V. \& BASTOS, M.N.C. 1999. Flórula fanerogâmica das restingas do estado do restingas do estado do Pará. Ilha de Algodoal. I - Família Turneraceae A. P. de Candolle. Boletim do Museu Paraense Emilio Goeldi série Botânica 15:173-198.

VILLWOCK, J.A. 1987. Processos costeiros e formação das praias arenosas e campos de dunas ao longo da costa sul-sudeste brasileira. In Simpósio sobre ecossistemas da costa sul-sudeste brasileira: Síntese dos conhecimentos 1. Academia de Ciências do Estado de São Paulo, p.380-398.

WESSEL, P. \& SMITH, W.H.F. 1996. A global self-consistent, hierarchical, high-resolution shoreline database. Journal of Geophysical Research 101:8741-8743.

ZULOAGA, F.O., MORRONE, O., DAVIDSE, G., FILGUEIRAS, T.S., PETERSON, P.M., SORENG, R.J. \& JUDZIEWICZ, E.J. 2003. Catalogue of New World grasses (Poaceae): III. subfamilies Panicoideae, Aristidoideae, Arundinoideae, and Danthonioideae. Contributions from the United States National Herbarium 46:1-662. 
